\title{
Article \\ Melatonin Protects Tobacco Suspension Cells against Pb-Induced Mitochondrial Dysfunction
}

\author{
Agnieszka Kobylińska and Małgorzata Maria Posmyk*D \\ Department of Plant Ecophysiology, Faculty of Biology and Environmental Protection, University of Lodz, \\ 90-237 Łódź, Poland; agnieszka.kobylinska@biol.uni.lodz.pl \\ * Correspondence: malgorzata.posmyk@biol.uni.lodz.pl
}

Citation: Kobylińska, A.; Posmyk, M.M. Melatonin Protects Tobacco Suspension Cells against Pb-Induced Mitochondrial Dysfunction. Int. J. Mol. Sci. 2021, 22, 13368. https:// doi.org/10.3390/ijms222413368

Academic Editor: Nicolas L. Taylor

Received: 31 August 2021

Accepted: 9 December 2021

Published: 13 December 2021

Publisher's Note: MDPI stays neutral with regard to jurisdictional claims in published maps and institutional affiliations.

Copyright: (c) 2021 by the authors. Licensee MDPI, Basel, Switzerland. This article is an open access article distributed under the terms and conditions of the Creative Commons Attribution (CC BY) license (https:// creativecommons.org/licenses/by/ $4.0 /)$.

\begin{abstract}
Recent studies have shown that melatonin is an important molecule in plant physiology It seems that the most important is that melatonin effectively eliminates oxidative stress (direct and indirect antioxidant) and switches on different defence strategies (preventive and interventive actions) during environmental stresses. In the presented report, exogenous melatonin potential to protect Nicotiana tabacum L. line Bright Yellow 2 (BY-2) exposed to lead against death was examined. Analyses of cell proliferation and viability, the level of intracellular calcium, changes in mitochondrial membrane potential $(\Delta \Psi m)$ as well as possible translocation of cytochrome $\mathrm{c}$ from mitochondria to cytosol and subsequent caspase-like proteolytic activity were conducted. Our results indicate that pretreatment BY-2 with melatonin protected tobacco cells against mitochondrial dysfunction and caspase-like activation caused by lead. The findings suggest the possible role of this indoleamine in the molecular mechanism of mitochondria, safeguarding against potential collapse and cytochrome $c$ release. Thus, it seems that applied melatonin acted as an effective factor, promoting survival and increasing plant tolerance to lead.
\end{abstract}

Keywords: BY-2 tobacco cells; caspase-like protease; cytochrome c; melatonin; mitochondria; programmed cell death

\section{Introduction}

Among the most significant soil contaminants resulting from both natural and manmade sources, heavy metals, and especially lead, are of prime importance due to their long-term toxicity effects [1]). Lead $(\mathrm{Pb})$ can be found in dust, fumes, mists, vapours and in soil as minerals $\left(\mathrm{PbCO}_{3}\right.$ - cerussite, $\mathrm{PbS}$ - galena, $\mathrm{PbSO}_{4}$-anglesite $)$ [1]. Lead is taken up via roots, along with water, or it can be absorbed from the air via shoots and foliage [2]. Unfortunately, plant roots are not highly selective and absorb excessively accumulated lead. It affects mineral uptake, inducing imbalances in essential and trace elements resulted from toxic ion competitions with macro- and microelements and their replacement in various biologically active substances [3,4]. Thus, the decrease of $\mathrm{P}, \mathrm{K}, \mathrm{Ca}, \mathrm{Cu}, \mathrm{Fe}, \mathrm{Mn}$ and $\mathrm{Zn}$ content in plant tissue, as a result of a possible blockage of the transporter proteins by lead, is observed $[2,3,5]$.

Moreover, a higher level of lead in plant tissues leads to alterations in photosynthesis, revealed as a limitation of net $\mathrm{CO}_{2}$ assimilation rate, decline of chlorophylls concentration due to the reduction of chlorophyll synthesis, and their degradation as well as destabilization of chloroplast structure $[5,6]$.

The latest literature data indicated that water-extractable lead (soils leachates), similarly to other heavy metals, are most likely involved in human DNA damage [7]-it is potentially mutagenic, capable of inhibiting DNA synthesis or interfering with DNA repair. The cytotoxic mechanisms of lead in plants are not entirely understood. It has been reported that lead as a non-redox heavy metal can induce enhanced accumulation of reactive oxygen species (ROS), contributing to the strong oxidative stress generation and 
causing lipid peroxidation, membrane dysfunction, protein damage, DNA injuries and cell death $[8,9]$.

Its toxic concentration inhibits the activity of key enzymes, e.g., acid phosphatase, esterases, peroxidases, and malic dehydrogenase, by reacting with their sulfhydryl groups. Moreover, in BY-2 tobacco suspension cells, lead was the cause of the so-called DNA laddering, which is one of the signs of programmed cell death (PCD) [10].

PCD plays a key role in plant development and responses to environmental stresses. In multicellular eukaryotes, it occurs as part of normal development or maintenance of tissue homeostasis and is therefore one of the critical mechanisms for survival [11]. Plant cells, similar to cells from other kingdoms, have the ability to self-destruct in a genetically controlled way, and the identification of key regulators of plant PCD has been the focus of many studies [12,13]. The signalling cascades of animal PCD are well examined in comparison to plants and have clearly defined molecular subroutines, as was described by the nomenclature committee on cell death [14]. However, despite the vast evolutionary distance between mammals and plants, there are some common features of their PCD, including: increased formation of vesicles, cytoplasmic condensation, nuclear condensation, DNA degradation into mono- or oligonucleosomal 140-180 [15] or into $50 \mathrm{kbp}$ fragments [16] fragments as well as translocation of cytochrome c (Cyt c) from mitochondria to the cytosol $[17,18]$. During PCD, plant release of Cyt c can occur as a result of many stimuli such as D-mannose, menadione, heat, sulphated lentinan and ROS [19-23], whereas the production of endogenous ROS (low level as signalling molecules) is often affected by fluctuations in intracellular calcium ion $\left(\mathrm{Ca}^{2+}\right)$ concentration. It is known that $\mathrm{Ca}^{2+}$ and calmodulin are the ubiquitous intracellular second messengers regulating a large array of biological processes in plants. Specificity of calcium-based signalling processes result from spatio-temporal dynamics and the origin of calcium signals [24].

Thus, variation of intracellular $\mathrm{Ca}^{2+} /$ calmodulin concentration could trigger the PCD process in plants $[25,26]$. It was shown that in the interaction between pathogen and plant, an increase of $\mathrm{Ca}^{2+}$-activated ROS generation (high level as anti-pathogen strategy) and induced hypersensitive response (HR)-like cell death [26]. In this case, an increase of cytoplasmic $\mathrm{Ca}^{2+}$ concentration in plant cells seems to be an essential prerequisite for stimulating plant emergency response and inducing the production of resistant compounds such as ROS [26,27]. According to Petrosillo et al. [28,29] mitochondrial-induced ROS production promotes translocation of Cyt $\mathrm{c}$ from mitochondria to cytosol and may occur by a two-step process wherein Cyt $\mathrm{c}$ is first dissociated from cardiolipin via cardiolipin peroxidation, which is then released into the extramitochondrial environment followed by permeabilization of the outer membrane, probably by interaction with voltage dependent anion channels $[28,29]$. However, the function of cytoplasmic Cyt $\mathrm{c}$ is still discussed, since Vacca et al. [30] found that Cyt $\mathrm{c}$ release depended on ROS production and takes part in activation of the caspase-like cascade, but it is does not always lead to PCD. Vacca revealed that in early steps after PCD induction, an immediate production of ROS occurs that promotes Cyt $\mathrm{c}$ release from intact mitochondria. The caspase-like proteases play no role in this phase, essentially being inactive. In the later phase after PCD induction, the released Cyt c contributes to activation in caspase-like proteases, resulting in degradation of Cyt c and cell death [30]. However, Martínez-Fábregas et al. [18] indicated that extramitochondrial Cyt $\mathrm{c}$ had a double role in causing living cells to die by activation of the proapoptotic pathway as well as by inhibiting pro-survival factors, including SET protein (which acts as an inhibitor of p53 acetylation and blocks both p53-mediated cell cycle arrest and apoptosis after stress) or luminal binding protein 1 and 2 (BiP1 and BiP2), whose overexpression increased cell tolerance to endoplasmic reticulum stress [18,31].

To reduce the negative impact of environmental stresses, including lead pollution and defending cells against damage, the best solution may be biostimulators, non-toxic substances of natural origin that improve and stimulate plant life processes (phytostimulators) differently than fertilizers or phytohormones, e.g., improving plant tolerance and protecting them against harmful factors [32]. It is known that melatonin ( $\mathrm{N}$-acetyl- 
5-methoxytryptamine) seems to have great biostimulatory potential. This indolamine may act as a factor, fortifying cells against multiple stresses such as cold [33], copper [34], cadmium [35], lead [9,10], high temperature [36], salt [37], pressure osmotic [38], drought stresses [39] and pathogen infection [40]. Melatonin also redirects carbohydrate metabolism during sugar starvation and induces gluconeogenesis to obtain basic energy substrates, which is another defence strategy to overcome adverse environmental conditions [41]. Analysis of proteome in corn embryo after hydropriming with melatonin led to identification of more than twenty additional proteins, among which are identified anti-stress proteins as well as ones responsible for defence and detoxification [42]. Melatonin is the only antioxidant that can induce the cascade of reaction, in which both melatonin and its metabolites, e.g., cyclic-3-hydroxymelatonin, 2-hydroxylmelatonin and especially N1-acetyl-N2-formyl-5-methoxykynuramine, function as ROS scavengers.

Since melatonin has amphiphilic characteristics, it may act as a hydrophilic and hydrophobic antioxidant. This fact, together with small-sized melatonin, makes it particularly able to migrate easily between cell compartments in order to protect them against excessive ROS. Maintenance the ROS homeostasis in plants is crucial because, as reported by Bolduc and Brisson as well as Kawai-Yamada et al. [43,44], bursts of oxidative metabolism leading to generation of ROS are one of the earliest events in PCD, induced by harmful environmental conditions in plant cells. This suggests that high levels of ROS mediate the signal network for defence gene induction, e.g., hsp, lea, cor, ecs [45], or for PCD of selected cells.

One of the primary sites of ROS formation and the first target of oxidative stress are mitochondria. This is why mitochondria require some mechanisms that reduce oxidative stress levels in order to protect against abiotic or biotic stresses. Among many specific ROSscavenging tools, melatonin seems to be a mitochondrial-targeted antioxidant. The current data suggest that melatonin is not only taken up by mitochondria, but these organelles, which is highly probable, also produce melatonin [46-48]. Our previous studies revealed that melatonin regulates ROS generation by modulation expression of Bax inhibitor-1, a protein that functions as a $\mathrm{Ca}^{2+} / \mathrm{H}^{+}$antiporter.

We demonstrated that significant increases in cells viability and beneficial effects of exogenous melatonin on Pb-exposed BY-2 cells are correlated with drastically decreasing in $\mathrm{O}_{2} \bullet-$ and $\mathrm{H}_{2} \mathrm{O}_{2}$ contents and with changes in the expression of BI- 1 protein-an ancient regulator of plant cell death. However, there is still relatively little knowledge about the mechanisms of action of melatonin on cytological level in plants during preservation against death.

The aim of this study was to further elucidate the mechanisms underlying Nicotiana tabacum L. (cv. Bright Yellow 2; BY-2) cells' resistance to exposure to lead by pre-treatment with melatonin, with particular emphasis on several signalling events in mitochondria. The selection of the in vitro plant model to be tested was dictated by the homogeneity of the material (suspension of undifferentiated cells) and the possibility of multiple repetitions of the experiments under the same strictly controlled conditions.

Obtained results provide strong evidence that lead induces cell death through dysfunction of mitochondria whilst melatonin induces biological responses to fortifying cells against environmental stress. The findings show that melatonin significantly limited the negative effects of this heavy metal and acted as a biostimulating, pro-survival factor.

\section{Results}

\subsection{Cell Growth and Viability after Lead Treatment}

Incubation of BY-2 cells with melatonin prior to lead exposure protected cells from death and slightly improved cell proliferation, especially in the log phase of growth. Growth rates of the $C$ and MEL cells were similar during all culture times. Lead stress was triggered by the addition of lead on the fourth day and immediately resulted in significant inhibition of tobacco cell proliferation; see variant $\mathrm{Pb}$ (Figure 1A). However, proliferation of the MEL $+\mathrm{Pb}$ cells was $30-40 \%$ higher in comparison to those that were lead-treated and not primed with melatonin- $\mathrm{Pb}$ (Figure 1A). This effect remained until the end of the BY-2 cell culture. 

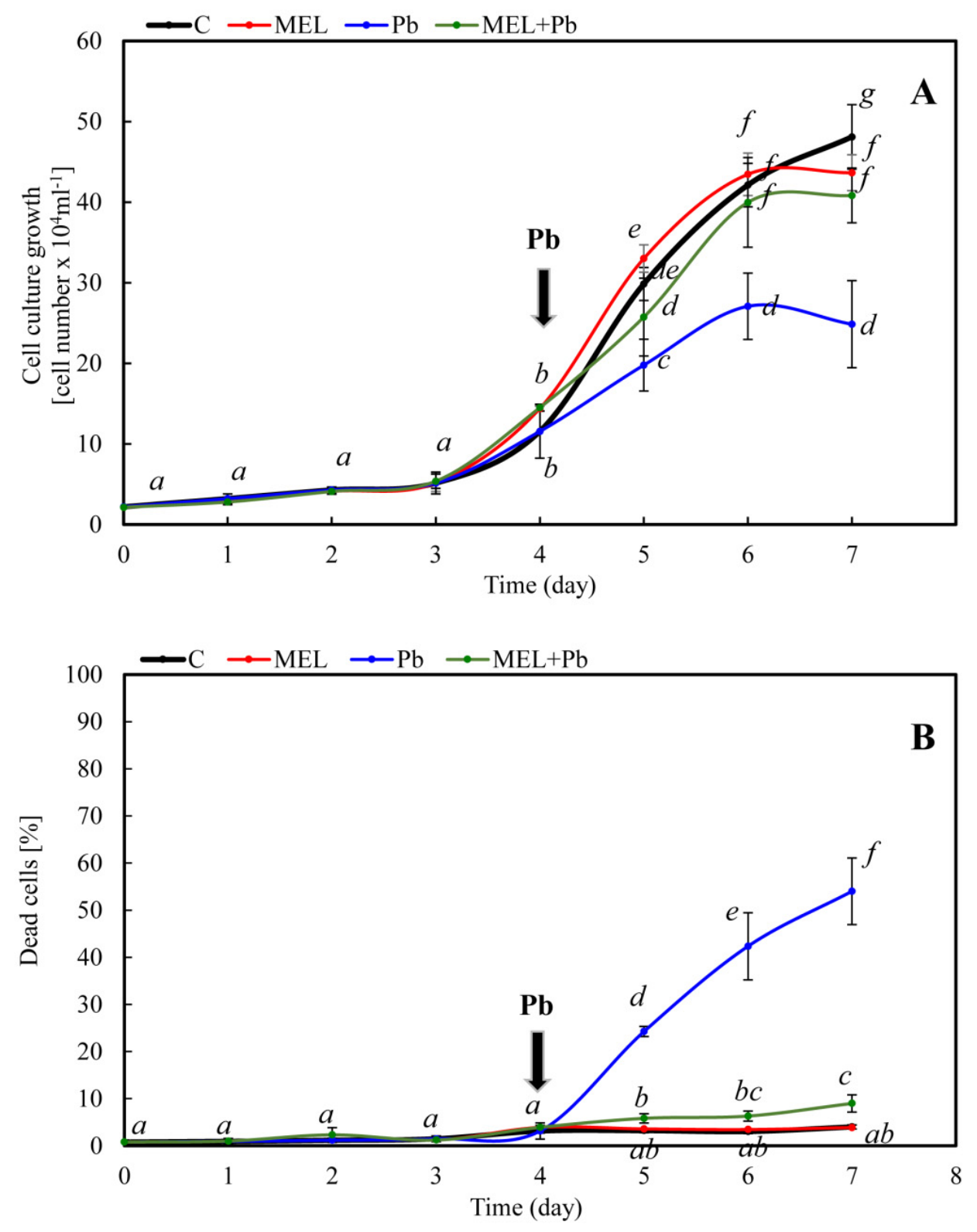

Figure 1. Kinetics of cell proliferation (A) and mortality (B) of BY-2 tobacco cells during conducted culture (0-7 days). Cell variants: C-BY-2 cells cultured on LS medium (the control variant); MEL-BY-2 cells cultured on LS medium with $200 \mathrm{nM}$ of melatonin added from the beginning of the culture; $\mathrm{Pb}-\mathrm{BY}-2$ cells cultured on LS medium with $15 \mu \mathrm{M} \mathrm{Pb}^{2+}$ added on the fourth day of the culture and MEL+Pb-BY-2 cells cultured on LS medium with melatonin added from the start of the culture and with $\mathrm{Pb}^{2+}$ added on the fourth day of culture. (A) Proliferation of ANOVA results: Variant $(\mathrm{C}, \mathrm{MEL}, \mathrm{Pb}, \mathrm{MEL}+\mathrm{Pb}) \mathrm{F}_{(3 ; 84)}=45.2 p<0.00001$; Day of culture $(0,1,2,3,4,5$, 6 , 7) $\mathrm{F}_{(7 ; 84)}=722.7 p<0.00001$; and interaction Variant $\mathrm{x}$ Day of culture $\mathrm{F}_{(21 ; 84)}=12.6 p<0.00001$. (B) Mortality ANOVA results: Variant $(\mathrm{C}, \mathrm{MEL}, \mathrm{Pb}, \mathrm{MEL}+\mathrm{Pb}) \mathrm{F}_{(3 ; 71)}=334.7 p<0.00001$; Day of culture $(0,1,2,3,4,5,6,7) \mathrm{F}_{(7 ; 71)}=165.6 p<0.00001$; and interaction Variant $\mathrm{x}$ Day of culture $\mathrm{F}_{(21 ; 71)}=98.4 p<0.00001$.

Conversely, the protective role of melatonin was evaluated by cell mortality assessment in all experimental samples. Methylene blue staining evidenced that culture medium supplementation with melatonin did not result in cell death acceleration. Surprisingly, obtained results revealed a comparable level of cell viability between lead-untreated cells $(\mathrm{C}$ and $\mathrm{MEL})$ and lead exposed but primed with melatonin ones (MEL $+\mathrm{Pb}$ ) (Figure 1B). 
Moreover, received data showed inhibitory effect of melatonin on cell death induced by lead. At the end of the $\log$ phase (the sixth day of culture; the second day after lead administration), mortality of BY-2 cells in $\mathrm{Pb}$ variants was $85 \%$ higher than in the MEL $+\mathrm{Pb}$ variant (Figure 1B).

\subsection{Measurements of Intracellular Calcium Level}

The level of the cytoplasm calcium was determined using the fluorescence probe Fluo-4-NW. Figure 2 shows that BY-2 cells primed with melatonin resulted in similar or only slightly decreased levels of the intracellular free calcium in comparison to control cells. Changes in the level of calcium ions were detectable after only $4 \mathrm{~h}$ of incubation with lead. A significant rise in the intensity of fluorescence probe was observed, especially during the longer time following lead treatment $(72 \mathrm{~h}$ ), and it was over $50 \%$ higher in comparison to control cells. Four and twenty-four hours after heavy metal exposition in the MEL $+\mathrm{Pb}$ variant, the intracellular free calcium level was similar to those without lead (MEL variant), whereas after $72 \mathrm{~h}$, the intensity of fluorescence probe was $20 \%$ higher than in MEL samples. The strongest evidence that melatonin limited concentration of intracellular calcium ions provided results of comparison between $\mathrm{MEL}+\mathrm{Pb}$ and $\mathrm{Pb}$ variants. Obtained results showed a $20 \%, 30 \%$ and over $40 \%$ lower level of the intracellular free calcium in MEL $+\mathrm{Pb}$ samples than in $\mathrm{Pb}$ ones for 4, 24 and $72 \mathrm{~h}$ after lead exposition, respectively.

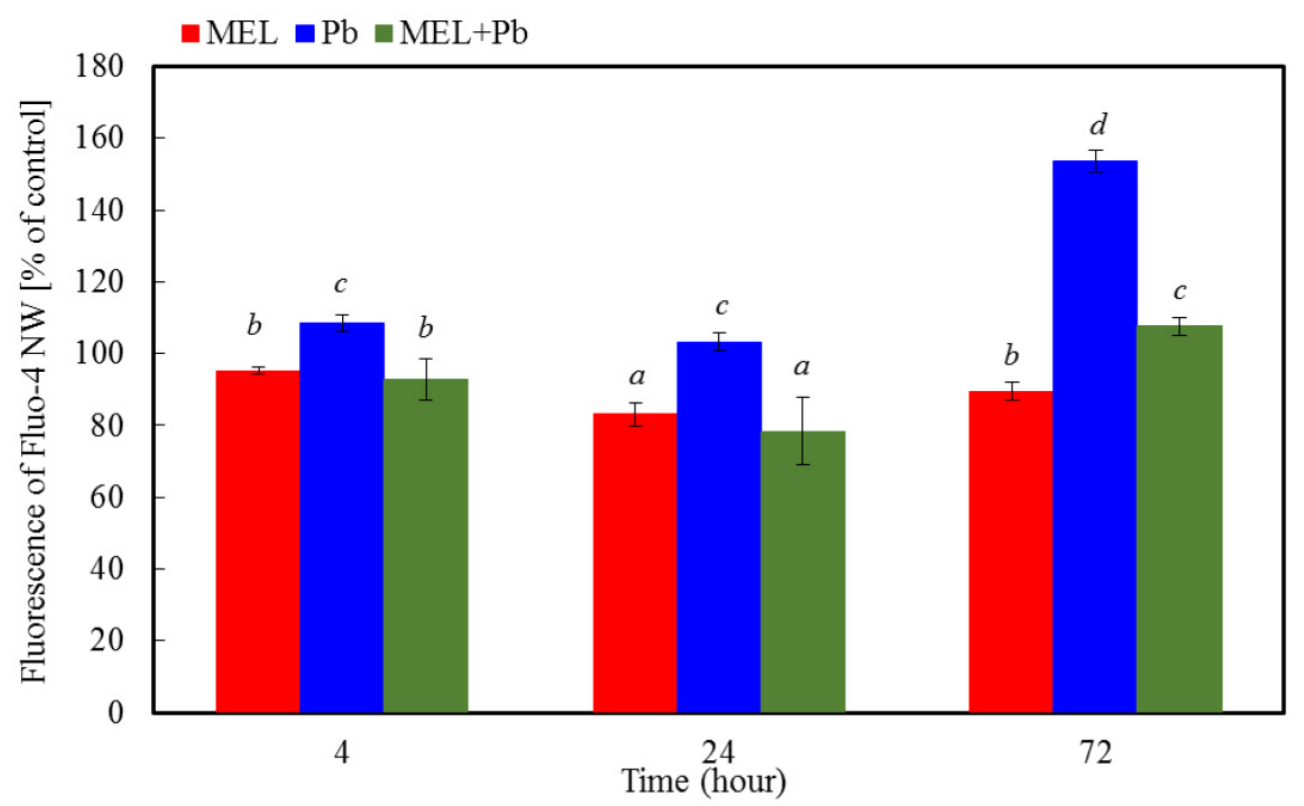

Figure 2. $\mathrm{Ca}^{2+}$ concentration in all experimental variants of BY-2 tobacco cells exposed to lead. Cell variants: C-BY-2 cells cultured on LS medium (the control variant); MEL-BY-2 cells cultured on LS medium with $200 \mathrm{nM}$ melatonin added from the beginning of the culture; $\mathrm{Pb}-\mathrm{BY}-2$ cells cultured on LS medium with $15 \mu \mathrm{M} \mathrm{Pb}^{2+}$ added on the 4th day of the culture; and MEL+Pb-BY-2 cells cultured on LS medium with melatonin added from the start of the culture and with $\mathrm{Pb}^{2+}$ added on the 4th day of culture. The intensity of Fluo-4-NW probe fluorescence was measured: 4, 24 and $72 \mathrm{~h}$ after lead treatment. Fluorescence of BY-2 control cells (C) above indicated that moments of the experiment were assumed as $100 \% . \mathrm{Ca}^{2+}$ concentration ANOVA results: Variant (MEL, $\mathrm{Pb}, \mathrm{MEL}+\mathrm{Pb}$ ) $\mathrm{F}_{(2 ; 18)}=157 p<0.00001$; Hours of $\mathrm{Pb}$ exposure $(4,24,72) \mathrm{F}_{(3 ; 18)}=104.7 p<0.00001$; and interaction Variant $x$ Hours of $\mathrm{Pb}$ exposure $\mathrm{F}_{(4 ; 18)}=30.9 p<0.00001$.

\subsection{Changes in Mitochondrial Membrane Potential ( $\Delta \Psi m$ )}

The changes in mitochondrial membrane potential were detected using the fluorescence dye JC-1. This probe has the unique property of spontaneously forming redfluorescent dimers under high mitochondrial potential, whereas its monomeric form, prevalent in cells with a low $\Delta \Psi m$, fluoresces in green. Thus, changes in the red/green fluo- 
rescence ratio reflect the variation of $\Delta \Psi m$. Figure 3 shows that preincubation of BY-2 cells with melatonin does not reflect a significant reduction in mitochondrial membrane potential. Up to $24 \mathrm{~h}$ of incubation, melatonin was observed to decrease the mitochondrial membrane potential only to $73.6 \pm 8.07 \%$ of control. The lowest level of this parameter was noted for lead-exposed cells $(\mathrm{Pb})$, and our observation indicated that already $4 \mathrm{~h}$ after lead treatment, it diminished to $39.85 \pm 9.9 \%$ of control. Prolonging the incubation time until $72 \mathrm{~h}$ resulted in gradual mitochondrial membrane depolarization $(24,79 \pm 3,19 \%$ of control). When the probes were preincubated with melatonin (MEL + Pb variant), the level of $\Delta \Psi m$ was about $50 \%$ higher in comparison to $\mathrm{Pb}$. Therefore, these results indicate efficiency of melatonin priming against collapse of mitochondrial membrane potential triggered by heavy metal stress (Figure 3).

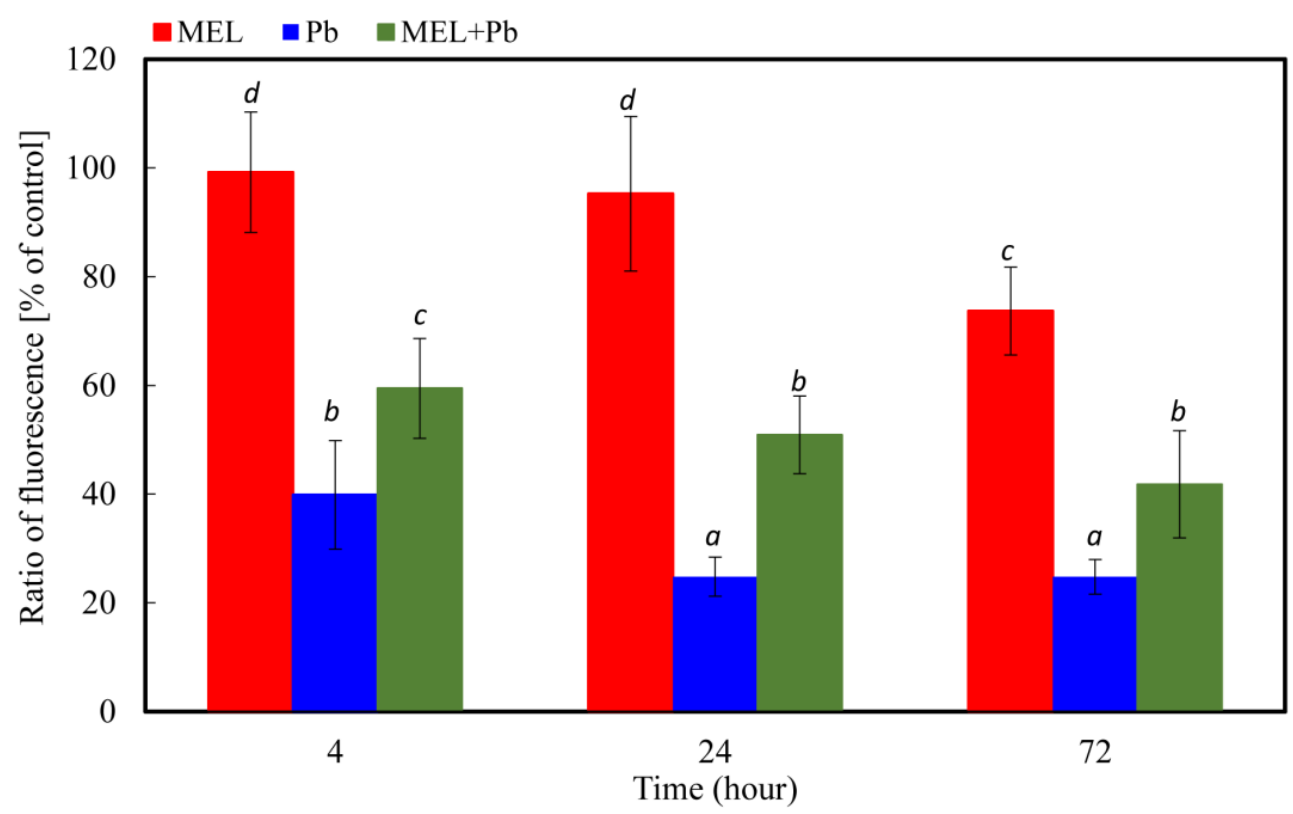

Figure 3. Changes in mitochondrial membrane potential $(\Delta \Psi m)$ of BY-2 tobacco cells in conducted experiments. Cell variants: C-BY-2 cells cultured on LS medium - the control variant; MEL-BY-2 cells cultured on LS medium with $200 \mathrm{nM}$ melatonin added from the beginning of the culture; $\mathrm{Pb}-\mathrm{BY}-2$ cells cultured on LS medium with $15 \mu \mathrm{M} \mathrm{Pb}^{2+}$ added on the 4th day of the culture; and $\mathrm{MEL}+\mathrm{Pb}-\mathrm{BY}-2$ cells cultured on LS medium with melatonin added from the start of the culture and with $\mathrm{Pb}^{2+}$ added on the 4th day of culture. Fluorescence ratio of JC- 1 dimers/JC- 1 monomers in BY-2 cells were measured 4, 24 and $72 \mathrm{~h}$ after lead treatment. Fluorescence of BY-2 control cells (C) in above indicated moments of the experiment were assumed as $100 \%$. Mitochondrial membrane potential ANOVA results: Variant $(\mathrm{MEL}, \mathrm{Pb}, \mathrm{MEL}+\mathrm{Pb}) \mathrm{F}_{(2 ; 43)}=185.3 p<0.00001$; Hours of $\mathrm{Pb}$ exposure $(4,24,72) \mathrm{F}_{(2 ; 43)}=20.6 p<0.00001$; and interaction Variant $x$ Hours of $\mathrm{Pb}$ exposure $\mathrm{F}_{(4 ; 43)}=2.2 p=0.084$

\subsection{Cytochrome c Translocation}

To further confirm the protective role of melatonin, immunodetection of Cyt c in mitochondrial and cytosolic fractions was examined. The literature data indicate that in plants, similar to in mammals, mitochondria are involved in cell death, and translocation of Cyt $c$ to cytosol seems to play an important role in PCD phenomena. Detection of this protein with an antibody recognizing whole Cyt c molecule was performed in mitochondrial pellet and cytosolic fraction, and subsequently, videodensitometry analysis of both fractions was performed.

In all experimental variants in the 4 th $\mathrm{h}$ after lead treatment, Cyt $\mathrm{c}$ was detected mainly in the mitochondrial pellet (Figure 4), despite significant decreasing at this time of the mitochondrial membrane potential. Comparable levels of Cyt $\mathrm{c}$ were detected both 
in mitochondrial pellet and cytosolic fractions of BY-2 cells in control (C) and melatonintreated samples (MEL and MEL $+\mathrm{Pb}$ ) in the $24 \mathrm{~h}$ after lead administration (Figure 4).

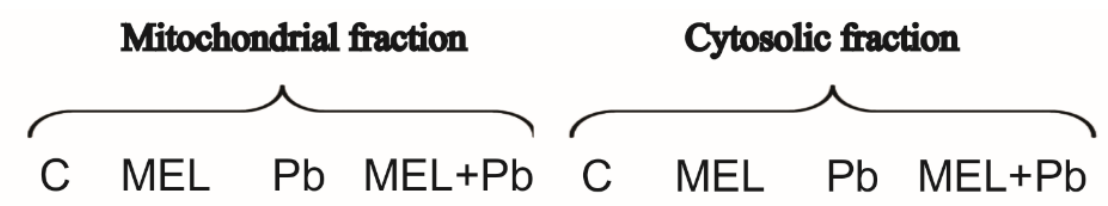

$4 \mathrm{~h}$
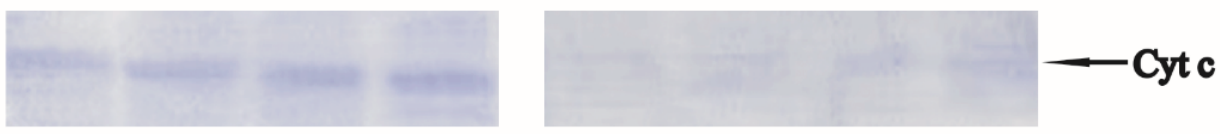

$24 \mathrm{~h}$
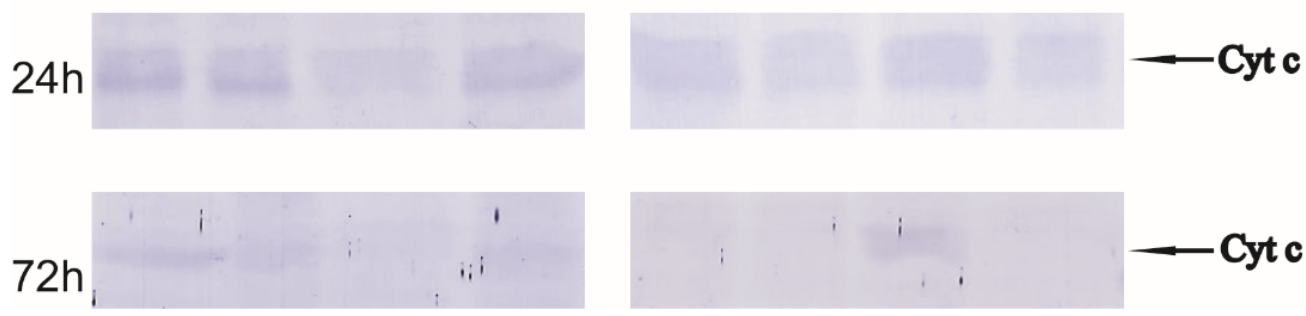

Figure 4. Translocation of cytochrome $\mathrm{c}$ protein from mitochondria to the cytosol fraction in all experimental variants: C-BY-2 cells cultured on LS medium, the control variant; MEL-BY-2 cells cultured on LS medium with $200 \mathrm{nM}$ melatonin added from the beginning of the culture; $\mathrm{Pb}-\mathrm{BY}-2$ cells cultured on LS medium with $15 \mu \mathrm{M} \mathrm{Pb}^{2+}$ added on the 4th day of the culture; and MEL $+\mathrm{Pb}-$ BY-2 cells cultured on LS medium with melatonin added from the start of the culture and with $\mathrm{Pb}^{2+}$ added on the 4 th day of culture. Cells were exposed to lead for 4, 24 and $72 \mathrm{~h}$. Then, samples were separated by SDS-PAGE and probed with antibodies to cytochrome c by Western blotting.

In $\mathrm{Pb}$ samples, relatively high release of $\mathrm{Cyt} \mathrm{c}$ from mitochondria to cytosol was observed at this time. The estimated integral density of immunostained polypeptide bands indicated about a 50\% higher Cyt c expression in cytosolic fraction in comparison to control (C) or melatonin-primed BY-2 cells (MEL and MEL $+\mathrm{Pb}$ ) (Figure 5). For BY-2 cells exposed to lead, extension of incubation time to $72 \mathrm{~h}$ resulted in almost complete disappearance of Cyt $\mathrm{c}$ in mitochondrial pellet and simultaneous accumulation of this protein in cytosolic fraction. Videodensitometric analysis showed increases of the cytosolic Cyt c expression level nearly two times above control and MEL value. Cells treated with melatonin and exposed to heavy metal (MEL $+\mathrm{Pb}$ ) were characterized by similar Cyt $\mathrm{c}$ expression in cytosol, versus lead-untreated ones. However, quantitative analysis showed $25 \%$ higher expression of Cyt $\mathrm{c}$ in comparison to $\mathrm{C}$ and MEL variants and 30\% lower Cyt c level relative to $\mathrm{Pb}$ (Figure 5). This cytological and molecular evidence demonstrated clearly that melatonin preincubation protected tobacco suspension cells from lead-induced death. 



Figure 5. Optical density of cytochrome $\mathrm{c}$ in mitochondrial and cytosolic fraction in all experimental variants: C-BY-2 cells cultured on LS medium, the control variant; MEL-BY-2 cells cultured on LS medium with $200 \mathrm{nM}$ melatonin added from the beginning of the culture; $\mathrm{Pb}-\mathrm{BY}-2$ cells cultured on LS medium with $15 \mu \mathrm{M} \mathrm{Pb}^{2+}$ added on the 4th day of the culture; and MEL+Pb-BY-2 cells cultured on LS medium with melatonin added from the start of the culture and with $\mathrm{Pb}^{2+}$ added on the 4 th day of culture. Cells were exposed to lead for 4,24 and $72 \mathrm{~h}$. Then, samples were separated by SDS-PAGE, probed with antibody to cytochrome $\mathrm{c}$ by Western blotting and subsequently videodensitometry analysis was perfromed. (A) Cytochrome $\mathrm{c}$ in mitochondrial fraction ANOVA results: Variant $(\mathrm{C}, \mathrm{MEL}, \mathrm{Pb}, \mathrm{MEL}+\mathrm{Pb}) \mathrm{F}_{(3 ; 16)}=36.5 p<0.00001$; Hours of Pb exposure $(4,24,72) \mathrm{F}_{(2 ; 16)}=261.5$ $p<0.00001$; and interaction Variant $x$ Hours of $\mathrm{Pb}$ exposure $\mathrm{F}_{(6 ; 16)}=10.1 p<0.0005$. (B) Cytochrome $\mathrm{c}$ in cytosolic fraction ANOVA results: Variant $(\mathrm{C}, \mathrm{MEL}, \mathrm{Pb}, \mathrm{MEL}+\mathrm{Pb}) \mathrm{F}_{(3 ; 12)}=17.4 p<0.0005$; Hours of $\mathrm{Pb}$ exposure $(4,24,72) \mathrm{F}_{(2 ; 12)}=57.5 p<0.00001$; and interaction Variant $\mathrm{x}$ Hours of $\mathrm{Pb}$ exposure $\mathrm{F}_{(6 ; 16)}=1.3 p=0.323$.

\subsection{Effect of $\mathrm{Pb}$ on Caspase-like Proteolytic Activity}

The activation of caspase-9 and -3-like proteases has been shown to occur during PCD in several plant systems, suggesting that some forms of plant PCD may have a caspase 
triggering pathway similar to the animal counterpart [23,49-51]. To measure LEHDase (caspase-9-like) and DEVDase (caspase-3-like) activities, total protein extracts from BY-2 suspension cells in all experimental variants were incubated with the synthetic tetrapeptide LEHD-pNA and DEVD-pNA, a specific substrate of caspase-9 and -3, respectively. Addition of the substrate resulted in a signal caused by the cleavage of the chromophore pNA from the labelled substrate. LEHDase and DEVDase activity was monitored after 4, 24 and $72 \mathrm{~h}$ of cell treatment with lead. Cells primed with melatonin and not exposed to heavy metal demonstrated lower or similar to control caspase-9 and -3-like proteolytic activity in all analysed times of culture. However, extremely high caspase-9-like activity was noticed in $\mathrm{Pb}$ variants, and it was about $35 \%, 55 \%$, and $50 \%$ higher in comparison to $\mathrm{C}$. We found the inhibition of LEHDase activity in cells incubated with melatonin and treated with lead $(\mathrm{MEL}+\mathrm{Pb})$. The strongest evidence was especially visible 24 and $72 \mathrm{~h}$ after heavy metal incubation, and for MEL + Pb samples, caspase-9-like proteolytic activity was over $90 \%$ lower than in $\mathrm{Pb}$ ones (Figure 6A). This investigation confirms that melatonin, to a large extent, is able to block/reverse the cytotoxic lead influence and protect tobacco cells against death caused by heavy metal. Similar effects were obtained for DEVDase. Figure 6B shows that BY-2 cells incubated with lead had enhanced caspase-3-like activities in all analysed time points after lead application. Nevertheless, the biggest differences in caspase-3-like activity between control and lead-treated cells $(\mathrm{Pb})$ were observed at the end of culture $(72 \mathrm{~h}$ after heavy metal application) and it was 10.9 versus $24.9 \mu \mathrm{M}$ pNA for $\mathrm{C}$ and $\mathrm{Pb}$, respectively. Usage of melatonin resulted in a reduction of caspase-3-like activity to a level similar to leaduntreated cells. Both caspase-like protease activities were significantly decreased by caspase inhibitors specific for each caspase: Ac-LEHD-CHO (for caspase-9) and Ac-DEVD-CHO (for caspase-3) (Figure 6A,B), validating presented data. These results suggest increasing caspase-like activity occurred during PCD of the tobacco suspension cells.
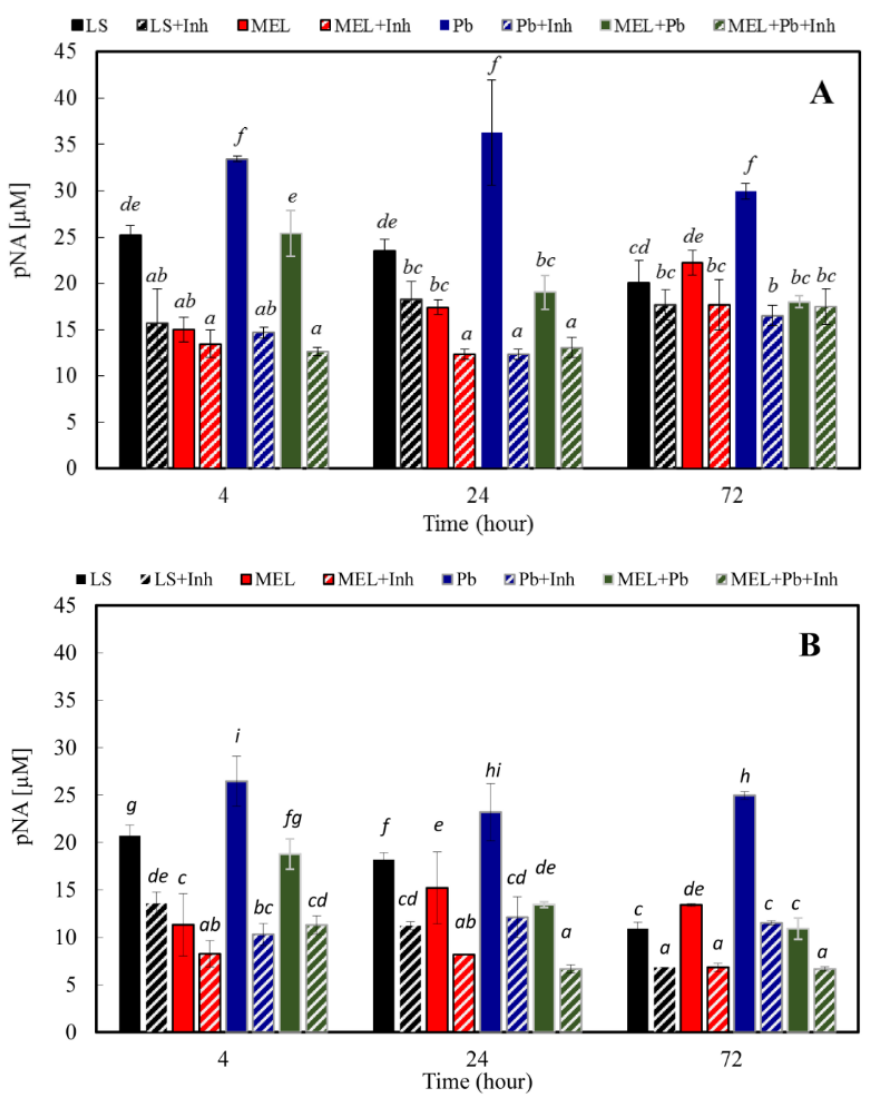

Figure 6. Measurements of caspase-like activities in tobacco cells: (A) caspase 9-like activity with (+Inh) or without the caspase-9 inhibitor Ac-LEHD-CHO; (B) caspase 3-like activity with (+Inh) or 
without the caspase-3 inhibitor Ac-DEVD-CHO. Cell variants: C-BY-2 cells cultured on LS medium (the control variant); MEL-BY-2 cells cultured on LS medium with $200 \mathrm{nM}$ melatonin added from the beginning of the culture; $\mathrm{Pb}-\mathrm{BY}-2$ cells cultured on LS medium with $15 \mu \mathrm{M} \mathrm{Pb}^{2+}$ added on the 4th day of the culture; and MEL + Pb-BY-2 cells cultured on LS medium with melatonin added from the start of the culture and with $\mathrm{Pb}^{2+}$ added on the 4 th day of culture. Caspase-like activities were measured 4, 24 and $72 \mathrm{~h}$ after lead exposure. (A) Caspase-9-like ANOVA results: Variant (LS, LS + Inh, MEL, MEL + Inh, Pb, PB + Inh, MEL + Pb, MEL + PB + Inh) $\mathrm{F}_{(7 ; 74)}=121 p<0.00001$; Hours of $\mathrm{Pb}$ exposure $(4,24,72) \mathrm{F}_{(2 ; 74)}=1.65 p=0.198$; and interaction Variant $x$ Hours of $\mathrm{Pb}$ exposure $\mathrm{F}_{(14 ; 74)}=9.5 p<0.00001$. (B) Caspase-3-like ANOVA results: Variant (LS, LS + Inh, MEL, MEL + Inh, $\mathrm{Pb}, \mathrm{PB}+$ Inh, MEL $+\mathrm{Pb}, \mathrm{MEL}+\mathrm{PB}+\mathrm{Inh}) \mathrm{F}_{(7 ; 87)}=180 p<0.00001 ;$ Hours of Pb exposure $(4,24,48)$ $\mathrm{F}_{(2 ; 87)}=45.5 p<0.00001$; and interaction Variant $x$ Hours of $\mathrm{Pb}$ exposure $\mathrm{F}_{(14 ; 87)}=13.6 p<0.00001$.

\subsection{Determination of Melatonin Levels}

To find out whether tobacco cells are able to actively absorb melatonin from culture media, the contents of this indoleamine in cell lysates were determined by HPLC-MS in lag, $\log$ and stationary phase of growth.

Generally, tobacco cells have melatonin content on a low level (Table 1). In not exposed to melatonin cells $(\mathrm{C}$ and $\mathrm{Pb})$, the level of this indoleamine slightly increased from zero (the 1st day of culture) to $\sim 1 \mathrm{ng} / \mathrm{g}_{\mathrm{FW}}$ (on the last day). In comparison with the melatoninprimed cells (MEL and MEL $+\mathrm{Pb}$ ) BY-2 cells are able to synthesize endogenous melatonin, but in extremely low levels. Moreover, in lead-treated cells $(\mathrm{Pb})$, the level of endogenous melatonin in comparison to the control (C) cells was about 30\% lower at the end of the culture period (7th day). The concentrations of melatonin drastically increased in the cells exposed to melatonin during the whole period of culture (Table 1). Obtained data indicated that BY-2 cells absorbed it gradually from the medium. Cells exposed to heavy metal stress condition and primed with melatonin (MEL $+\mathrm{Pb}$ ) absorbed this indoleamine about $20 \%$ more intensively than MEL cells.

Table 1. Melatonin concentration (ng $\mathrm{gEL}_{\mathrm{M}} / \mathrm{g}_{\mathrm{FW}}$ ) in homogenates of BY-2 cells in in all experimental variants: C-BY-2 cells cultured on LS medium - the control variant; MEL-BY-2 cells cultured on LS medium with $200 \mathrm{nM}$ melatonin added from the beginning of the culture; $\mathrm{Pb}-\mathrm{BY}-2$ cells cultured on LS medium with $15 \mu \mathrm{M} \mathrm{Pb}^{2+}$ added on the 4th day of the culture; and MEL+Pb-BY-2 cells cultured on LS medium with melatonin added from the start of the culture and with $\mathrm{Pb}^{2+}$ added on the 4th day of culture. Measurements were conducted 4, 24 and $72 \mathrm{~h}$ after $\mathrm{Pb}$ treatment.

\begin{tabular}{ccccc}
\hline \multirow{2}{*}{ Time (h) } & \multicolumn{4}{c}{ BY-2 Cell Variants } \\
\cline { 2 - 5 } & $\mathbf{C}$ & MEL & Pb & MEL + Pb \\
\hline 4 & $0.00 \pm 0.00 a$ & $6.68 b \pm 0.13 b$ & $0.00 \pm 0.00 a$ & $6.68 \pm 0.13 b$ \\
24 & $0.73 \pm 0.02 a$ & $15.08 c \pm 1.59 c$ & $0.73 \pm 0.02 a$ & $15.08 \pm 1.59 c$ \\
72 & $0.95 \pm 0.04 a$ & $33.24 d \pm 3.19 d$ & $0.68 a \pm 0.04 a$ & $40.75 e \pm 3.25 d$ \\
\hline
\end{tabular}

Melatonin ANOVA results: Variant $(\mathrm{C}, \mathrm{MEL}, \mathrm{Pb}, \mathrm{MEL}+\mathrm{Pb}) \mathrm{F}_{(3 ; 59)}=831.9 p<0.00001$; Hours of $\mathrm{Pb}$ exposure $(4,24,72) \mathrm{F}_{(2 ; 59)}=600.1 p<0.00001$; and interaction Variant $x$ Hours of $\mathrm{Pb}$ exposure $\mathrm{F}_{(6 ; 59)}=190.8 p<0.00001$.

\section{Discussion}

Plant cells have the ability to self-destruct in a controlled manner, called programmed cell death. Unlike death as a consequence of physical damage, which is not controlled by the cell itself, PCD is genetically regulated. PCD is a versatile tool for plants to cope with various situations or needs. Within plant systems, PCD falls within two broad categories, developmentally regulated and environmentally induced. In development, tracheary elements for example, undergo PCD to form the xylem; moreover, deletion of the embryonic suspensor, anther dehiscence, leaf and flower senescence or leaf morphogenesis also belong to developmentally regulated PCD [52-54]. PCD also plays an important role in plants exposed to a broad range of biotic and abiotic stress stimuli such as pathogen-plant reactions, UV radiation, heat shock and heavy metals, e.g., aluminium, coper, cadmium or 
lead [9,54-56]. Our previous studies indicated that lead-induced PCD manifested on the cytological level by ROS accumulation leading to DNA fragmentation and cell death [10].

This report regards the involvement of mitochondria in lead-induced cell death and the protective effect of melatonin on in vitro plant suspension cells exposed to lead stress.

At the first part of this study, cell proliferation and viability under optimal ( $\mathrm{C}$ and $\mathrm{MEL}$ ) and heavy metal stress condition ( $\mathrm{Pb}$ and $\mathrm{MEL}+\mathrm{Pb}$ ) were investigated. Nicotiana tabacum BY-2 cells cultivated on LS medium supplemented with melatonin (MEL) did not significantly change cell development profiles. Both levels of cell proliferation as well as their mortality were similar to non-treated control cells cultivated under optimal conditions. Positive effects of melatonin were visible during lead stress. Proliferation of cells pre-treated with melatonin under heavy metal stress condition (MEL $+\mathrm{Pb})$ was only slightly worse in comparison to lead-unstressed variants (C and MEL), whereas in $\mathrm{Pb}$ probes, a significantly lower proliferation level was observed (about $50 \%$ of control cells). Conversely, the protective role of melatonin was evaluated by cell mortality in all experimental samples. We expect that the number of dead cells in $\mathrm{Pb}$ variant increased drastically during heavy metal stress. However, we did not suppose that such high viability would be obtained in a melatonin pre-incubated cell variant exposed to heavy metal $(\mathrm{MEL}+\mathrm{Pb})$, where its viability was about $80 \%$ higher than in $\mathrm{Pb}$ cells. Our results are in line with many previous results, which also indicate that positive effects of plant melatonin treatments do not appear under optimal conditions, but this indoleamine can act as a factor fortifying cells against potentially stress conditions before it appears [9,34].

It is well established that melatonin exerts the antiapoptotic action in various animal cells, and the basis of this action is associated with its antioxidant properties [57-60]. Although the significance of melatonin for plant life is still being intensively studied, the current knowledge is mainly focused on the role of melatonin as an antioxidant factor, which takes part in direct scavenging of ROS and RNS [61], acceleration of antioxidant enzymes activity [33], protection against oxidative damage leading to cell death [62], and synergistic actions with other antioxidants [63]. Melatonin is also a growth promoter that limits cell death by inhibition of machinery, leading to DNA laddering $[10,64]$ or by influence on BI-1 protein, which overexpression in plants improved cell survival against elicitors of plant fungi $[65,66]$ or heavy metals [9]. To elucidate the mechanism of melatonin action against PCD limitation induced by lead, we tested the main biochemical hallmarks of cell death, such as the changes in intracellular calcium, changes in mitochondrial membrane potential, the level of Cyt $\mathrm{c}$ and LEHDase and DEVDase activity. Mitochondrial $\mathrm{Ca}^{2+}$ overload is, in animals, one of the pro-apoptotic ways to induce the swelling of mitochondria, with perturbation or rupture of the outer membrane, and in turn, the release of some mitochondrial apoptotic factors, such as Cyt c into the cytosol [67]. In plant cells, it is also widely recognized that intracellular $\mathrm{Ca}^{2+}$ is an important regulator of PCD [26,27,68]. Our research indicated that BY-2 cells primed with melatonin demonstrated similar or only slightly decreased levels of intracellular free calcium in comparison to control cells. However, changes in the intensity of fluorescence were detectable after only $4 \mathrm{~h}$ of incubation with lead. A significant rise in level of calcium ions was observed, especially during the longer time following lead treatment $(72 \mathrm{~h})$, and it was over $50 \%$ higher in comparison to the control cells. Simultaneously, in the MEL $+\mathrm{Pb}$ variant, the intracellular free calcium level was similar to those without lead. The strongest evidence that melatonin limited the concentration of intracellular calcium ions provided results of comparison $\mathrm{MEL}+\mathrm{Pb}$ vs. Pb samples. Obtained results showed time-dependent reduction of the intracellular free calcium in MEL $+\mathrm{Pb}$ cells vs. Pb ones. Conversely, Kacprzyk et al. [69] showed that the activation of the PCD pathway depends on one initial $\mathrm{Ca}^{2+}$-dependent trigger, rather than a series of calcium influxes throughout the death process. It was also demonstrated that blocking the extracellular $\mathrm{Ca}^{2+}$ influx was accompanied by a corresponding decrease in the level of early DNA fragmentation, which is another marker of PCD. Results obtained in the laboratory of Li et al. [26] explained the time discrepancies in $\mathrm{Ca}^{2+}$ level and DNA fragmentation. According to them, intracellular calcium ions could 
be divided into cytoplasmic calcium $\left(\left[\mathrm{Ca}^{2+}\right] \mathrm{cyt}\right)$ and nuclear calcium $\left(\left[\mathrm{Ca}^{2+}\right]\right.$ nuc. The rise of $\left[\mathrm{Ca}^{2+}\right]$ cyt could promote the production of ROS in cells, and the PCD process is induced by the gradually increasing concentration of ROS. However $\left[\mathrm{Ca}^{2+}\right]$ nuc is an important factor triggering nuclease and serine protease activity in the nucleus [26]. In addition, the experimental results implied that the increase of $\left[\mathrm{Ca}^{2+}\right]$ nuc concentration is necessary for the occurrence of $\mathrm{PCD}$, but $\left[\mathrm{Ca}^{2+}\right]$ nuc would only be induced until the intracellular ROS has gradually accumulated to a higher level. These data seem to support the hypothesis of Collazo et al. [70] that the NO/ROS ratio may induce a set of defence responses, including cleavage of an inhibitor of caspase-activated DNAse (ICAD) [70,71]. It is also in line with our previous report that DNA fragmentation was observed before Cyt $\mathrm{c}$ translocation to cytosol [10]. The mechanisms of Cyt $\mathrm{c}$ release inhibition by melatonin are still unknown. In animals, Suofu et al. [72] delineated a mitochondrial mechanism contributing to the protective action of melatonin against cell death. The high-affinity of melatonin and 2-[125I]-iodomelatonin for binding to melatonin receptors located in the outer membrane of mitochondria was established. Further described were mitochondrial melatonin type 1 receptors responding to melatonin by activating heterotrimeric $G$ proteins located in the intermembrane space, blocking adenylate cyclase activity and inhibition of $\mathrm{Ca}^{2+}$ dependent, stress-mediated Cyt $\mathrm{c}$ release, and in consequence, damping of caspase activation. Our results revealed gradual mitochondrial membrane depolarization after lead treatment. However, when the probes were preincubated with melatonin (MEL $+\mathrm{Pb}$ ), the level of $\Delta \Psi m$ was about $50 \%$ higher in comparison to $\mathrm{Pb}$ alone. It was compatible with data of Cyt c translocation from mitochondria to cytosol. Western blot and subsequent videodensitometric analysis showed increases of the cytosolic fraction of Cyt c expression in lead-treated BY-2 cells, nearly two times above control and MEL values. Cells treated with melatonin and exposed to heavy metal $(\mathrm{MEL}+\mathrm{Pb})$ were characterized by similar Cyt c expression in cytosol to lead-untreated ones. In mammals, following the outflow of Cyt c from mitochondria apoptosome, a heptameric structure consisting of Apaf-1 protein, ATP, Cyt c, and procaspase- 9 is formed, and this key factor leads to the activation of caspase cascade and cell death. While caspase activities have been detected in plants, sequences similar to animal caspases are not present in plant genomes. The metacaspases with weak structural similarity to caspases are likely involved in PCD [73,74], but do not execute caspase-specific proteolytic activity, recognizing substrates with either lysine or arginine instead of aspartate [75]. Other plant proteases with limited similarity to animal caspases display caspase-like activities and are involved in diverse types of PCD. In particular, vacuolar processing enzyme (VPE), also called legumain, is responsible for caspase- 1 activity in plants [76]. In turn, the $20 \mathrm{~S}$ proteasome, composed of many $\alpha$ and $\beta$ subunits, executes caspase-3 activity in response to biotic stress [77]. Wang et al. [23] observed activation of LEHDase and DEVDase during programmed cell death induced by sulphated lentinan in BY-2 cells, whereas Tran et al. [74] showed an increase in cascade of caspase-1, -3, -4, -6 and -8-like (excluding caspase-9-like) activities in the endosperm fraction during early development of barley caryopsis; however, in the maturating endosperm, an increase of all above caspase-like activities, including of caspase-9-like, was detected.

Our results demonstrated LEHDase and DEVDase activity in all analysed time points after lead exposition. However, cells primed with melatonin and lead-untreated (MEL) demonstrated lower or similar to control caspase-9 and -3-like proteolytic activity. Obtained data revealed about a 50\% increase in caspase-9-like activity after lead administration in comparison to control. Conversely, incubation of BY-2 cells with melatonin before heavy metal exposition $(\mathrm{MEL}+\mathrm{Pb})$ resulted in the inhibition of LEHDase and DEVDase activity. This investigation confirms that melatonin, to a large extent, is able to block/reverse the cytotoxic lead influence and protect tobacco cells against death caused by heavy metal, and it seems that the mechanism of this inhibition is achieved via mitochondria.

Several data collected in the review by Reiter et al. [47] show that melatonin is an important mitochondria-targeted antioxidant. This indoleamine not only prevents oxidative stress, but it also enhances mitochondrial antioxidant enzymes, improving the 
efficiency of electron transport in the mitochondrial chain as well as preventing the PCD pathway $[46,48,78]$. In transgenic Arabidopsis lines ectopically expressing MzSNAT5 gene, significantly higher melatonin production was observed, and surprisingly, synthesis of this indoleamine took place in mitochondria [48]. Moreover, in mammals, new transport systems, namely GLUT/SLC2A and PEPT1/2, were shown to have an active role in facilitating melatonin transport across membranes. Furthermore, the localization of these two transport systems in the mitochondria strongly suggests the participation of both in-mitochondrial transport of melatonin $[46,79,80]$.

Results of our research indicate that tobacco BY-2 cells were able to synthesize various, small amounts of this indoleamine, depending on the phase of growth as well as to absorb it actively from the medium. Availability of exogenous melatonin allowed BY-2 cells to uptake its large quantities throughout the culture period. Its levels at the end of culture were over 30 to 60 times higher in MEL and MEL + $\mathrm{Pb}$ in comparison to $\mathrm{C}$ and $\mathrm{Pb}$, respectively. The similar effects were observed by Kołodziejczyk et al. [81] in the case of cucumber and corn seeds, which were osmo- or hydroprimed with exogenous melatonin—corn seeds absorbed great quantities of this indoleamine proportional to its concentration applied during priming. Moreover, our previous data also revealed that, in sugar-starved BY-2 cells exposed to melatonin, the level of this indoleamine was much more higher than in sugar-starved but melatonin-untreated cells [41]. It could suggest that BY-2 cells absorb exogenous melatonin more readily and in larger quantities to counteract stress-induced cell death.

In conclusion, we indicate that melatonin successfully reverses the toxic influence of lead and protects plant cells against death. However, taking the newest literature data and our results into account, it seems probable that many PCD-protected functions could be explained on the basis of the melatonin presence in mitochondria; for this purpose, further studies of proteins and gene expression (involved in plant's PCD) in the investigated experimental model are planned.

\section{Materials and Methods}

\subsection{Cell Culture and Growth Conditions}

BY-2 suspension cells were routinely propagated and cultured at $25{ }^{\circ} \mathrm{C}$. From the stationary growth phase (day 7th) of the base culture, $2 \mathrm{~mL}$ of cell suspension was passaged into the fresh LS medium as a control (C) and LS with $200 \mathrm{nM}$ melatonin (MEL). The optimal dose of melatonin was chosen experimentally. In the middle of the logarithmic phase of growth (day 4th) $\mathrm{Pb}\left(\mathrm{NO}_{3}\right)_{2}$ was added to LS $(\mathrm{Pb})$ and LS with melatonin (MEL $+\mathrm{Pb}$ ) media to the final $\mathrm{Pb}^{2+}$ concentration of $15 \mu \mathrm{M}$. The applied concentration of lead was chosen after measurement of $\mathrm{LC}_{50}$ on the 7th day. Thus, the experiments were performed in four variants: (i) C: BY-2 cells cultured under optimal conditions on LS medium; (ii) MEL: BY-2 cells cultured on LS medium supplemented with melatonin from the start of new culture; (iii) $\mathrm{Pb}$ : BY-2 cells cultured on LS medium with $\mathrm{Pb}^{2+}$ added on the 4th day of culture; and (iv) MEL+Pb: BY-2 cells cultured on LS medium with melatonin added from the start of culture and stressed with $\mathrm{Pb}^{2+}$ added on the 4th day of culture. The cultures were maintained to the 7th day (stationary phase of the control cell growth).

\subsection{Determination of Cell Growth and Viability}

The cell number was determined with the use of a Fuchs-Rosenthal haemocytometer under a light microscope Olimpus CX-31 equipped with MicroScan v.15. digital system of image analysis; additionally, the number of dead cells was assessed after selective staining with methylene blue. Living cells do not take up the stain and retain their natural colour, whereas damaged cells are stained blue, as they are unable to keep the methylene blue from penetrating their membranes. The number of cells and their viability were analysed every experimental day. 


\subsection{Intracellular Calcium Ions Detection}

Intracellular calcium level was determined using the fluorescent probe Fluo-4NW, which is able to cross the plasma membrane of living cells. After entering the cell, Fluo$4 \mathrm{NW}$ is converted by cytosolic hydrolases to the active form, having the possibility of binding of calcium ions. As a result of joining of calcium ions, the probe emits fluorescence $\left(\lambda_{\mathrm{em}}=538 \mathrm{~nm}\right)$ after excitation with light of wavelength $485 \mathrm{~nm}$. Tobacco BY 2 cells in all experimental variants were plated in 96-well black fluorometric plates ( $2 \mathrm{mg}$ cells/well) and washed with PBS in order to eliminate sources of baseline fluorescence. Finally, a dye loading solution (Fluo-4-NW dye, 4-[(Dipropylamino)sulfonyl] benzoic acid (Probenecid) was used to inhibit extrusion of the indicator out of the cell by organic anion transporters. Hanks' balanced salt solution (HBSS), $20 \mathrm{mM} \mathrm{N}$-(2-hydroxyethyl)piperazine- $\mathrm{N}^{\prime}$-(2-ethanesulfonic acid) buffer solution (HEPES) was added in a volume of $100 \mu \mathrm{L}$ per well and incubated for $30 \mathrm{~min}$ in the total darkness at $37^{\circ} \mathrm{C}$, and then for the next $30 \mathrm{~min}$ at room temperature. The measurement was performed on Fluoroskan Ascent FL microplate reader (Labsystems, Sweden) using $494 \mathrm{~nm}$ excitation and $516 \mathrm{~nm}$ emission wavelengths.

\subsection{Mitochondrial Membrane Potential $(\Delta \Psi m)$}

Cells with all experimental variants were seeded into black 96-well titration microplates and incubated with $5 \mu \mathrm{M} \mathrm{JC}-1$ in HBSS for $30 \mathrm{~min}$ at $37 \mathrm{C}$ in the dark. JC-1 is a fluorescent carbocyanine dye which accumulates in the mitochondrial membrane in two forms (monomers or dimers), depending on mitochondrial membrane potential. JC-1 monomers show maximum fluorescence excitation and emission at 485 and $538 \mathrm{~nm}$ wavelengths, respectively. Negative potential of the inner mitochondrial membrane facilitates the formation of dye aggregates, which results in the shift of JC-1 monomer fluorescence towards red light $(\lambda \mathrm{ex}=530 \mathrm{~nm}$ to $\lambda \mathrm{em}=590 \mathrm{~nm})$ [82]. Thus, the measurement of the JC-1 dimer to monomer fluorescence ratio is a convenient and reliable method for the estimation of changes in mitochondrial membrane potential. The fluorescence of both JC- 1 monomers and dimers was measured with a Fluoroskan Ascent FL microplate reader (Labsystems, Stockcholm, Sweden). Prior to fluorescence measurements, the cells were washed twice with HBSS to remove the dye that may have adsorbed to the plastic microplate wells and disturbed the measurements. The results are expressed as a ratio of dimer to monomer fluorescence in relation to the control fluorescence ratio, taken as $100 \%$.

\subsection{Cell Fractionation}

Fractionation of cells was performed using the digitonin method according to Ganju and Eastman, with modification of Kobylińska et al. [83,84]. In all experimental variants, the cells were washed twice with PBS and next permeabilized for $30 \mathrm{~min}$ in a buffer containing: $1 \mathrm{mM} \mathrm{NaH} \mathrm{PO}_{4}, 8 \mathrm{mM} \mathrm{Na}_{2} \mathrm{HPO}_{4}, 75 \mathrm{mM} \mathrm{NaCl}, 250 \mathrm{mM}$ sucrose, digitonin ( $0.05 \%$ of cells weight), $20 \mu \mathrm{L} / \mathrm{g}$ cells $1 \mathrm{mM}$ phenylmethylsulfonyl fluoride (proteases inhibitor), and cocktail of enzymes for cell wall lysis (CelLytic Sigma). Cell homogenate was obtained by centrifugation at $3000 \times g$ for $1 \mathrm{~min}$. at $4{ }^{\circ} \mathrm{C}$ to remove cell debris. The cleaned homogenate after centrifugation at $12,000 \times g$ was divided into two fractions: the supernatant was removed as the cytosolic fraction and the pellet (mitochondrial fraction) was resuspended in the above buffer (without digitonin). To both fractions, sufficient volumes of Laemmli sample buffer supplemented with 10\% $\beta$-mercaptoethanol were added [85], and the mixtures were boiled for $5 \mathrm{~min}$.

\subsection{Western Blot Analysis}

Fractionated BY-2 cell lysates (50 $\mu$ g of proteins) were electrophoretically separated by sodium dodecyl sulphate polyacrylamide gel electrophoresis (SDS-PAGE) on 15\% gel [85] and transferred to Immobilon $\mathrm{PSQ}$ at the voltage of $20 \mathrm{~V}$ overnight at $4{ }^{\circ} \mathrm{C}$, according to Towbin et al. [86]. After blocking in 3\% nonfat dry milk in TBST (10 mM Tris-HCl, $\mathrm{pH} 7.5,150 \mathrm{mM} \mathrm{NaCl}, 0.05 \%$ Tween-20) for $60 \mathrm{~min}$, the membranes were incubated with primary antibodies specific to Cyt c in TBST in a cold room overnight. Subsequently, the 
membranes were washed several times in TBST and incubated with appropriate secondary antibodies conjugated with alkaline phosphatase (Sigma Chemical Co.) in TBS for $2 \mathrm{~h}$ at room temperature. Next, the membranes were washed several times with TBST. The proteins were visualized by incubation with the substrate solution $(0.33 \mathrm{mg} / \mathrm{mL}$ of nitro blue tetrazolium, $0.17 \mathrm{mg} / \mathrm{mL}$ of 5-bromo-4-chloro-3-indolyl phosphate in $100 \mathrm{mM}$ Tris$\mathrm{HCl}, \mathrm{pH} 9.5,100 \mathrm{mM} \mathrm{NaCl}$ and $5 \mathrm{mM} \mathrm{MgCl} 2$ ), prepared according to Leary et al. [87] and subsequently, videodensitometry analysis was performed (GelAnalyzer 2010a.).

\subsection{Measurements of Caspase-like Activities}

Caspase-9 (LEHDase) and caspase-3-like (DEVDase) activities were determined using the Caspase-9 and Caspase-3 Colorimetric Activity Assay Kits (EMD Millipore, Germany), respectively, according to the manufacturer's instructions. The assays are based on spectrophotometric detection of the chromophore pNA after the caspase-dependent cleavage from the labelled substrates LEHD- $p$ NA or DEVD- $p$ NA by active caspase- 9 or -3 , respectively. Cytosolic protein extracts from tobacco BY-2 cells after cell wall lysis were incubated for $2 \mathrm{~h}$ at $37^{\circ} \mathrm{C}$ with LEHD- $p$ NA or DEVD- $p$ NA in the presence or absence of $3 \mu \mathrm{M}$ caspase inhibitors Ac-LEHD-CHO (for caspase-9) or Ac-DEVD-CHO (for caspase-3) before spectrophotometric quantification of the free pNA $(\lambda=405 \mathrm{~nm})$. There were three independent replicates.

\subsection{Melatonin Determination}

Melatonin was extracted according to the modified methods of Guerrero et al. and Hernandez- Ruiz et al. $[88,89]$. Its concentration was measured on the 1st, 4 th and 7th day, which corresponds to lag, $\log$ and the stationary phases of growth. After filtration and separation of the cells from the medium, concentrations of melatonin in the extracts were determined using high-performance liquid chromatography (HPLC-MS/MS). For extraction, $5 \mathrm{~g}$ of fresh weight of the cells was homogenized with $5 \mathrm{~mL}$ of $50 \mathrm{mM}$ sodium phosphate buffer ( $\mathrm{pH}$ 8.0) containing $1 \mathrm{mM}$ EDTA and $5 \mu \mathrm{M}$ butylated hydroxytoluene (BHT) as an antioxidant. The homogenate was maintained for $15 \mathrm{~h}$ at room temperature in darkness with minimal shaking in order to ensure complete extraction of melatonin.

Then, it was centrifuged at $1500 \times g$ for $10 \mathrm{~min}$ at $5{ }^{\circ} \mathrm{C}$. Initial purification consisted of two steps by solvent partitioning using ethyl acetate and $50 \mathrm{~mm}$ sodium phosphate buffer (first at $\mathrm{pH} 8.0$ and second at $\mathrm{pH}$ 3.0). The two organic phases were evaporated together under vacuum. Dry residue was re-dissolved in $1 \mathrm{~mL}$ of mobile phase, filtered through Supelco ISO-Disc filters (PTEF-4-2.4 $\mathrm{mm} \times 0.2 \mathrm{~m}$; Supelko, Bellefonte, PA, USA), and frozen at $-70{ }^{\circ} \mathrm{C}$ until HPLC-MS analysis. The purified extract was subjected to HPLCMS/MS analysis using an Agilent 1200 LC System coupled with AB Sciex 3200 QTRAP mass detector equipped with TurboSpray Ion Source (ESI). Each sample was injected onto Agilent SB-C18 column.

\subsection{Statistical Analysis}

The data represent the means \pm standard deviation $( \pm S D)$. The data were analysed using STATISTICA v.10.0_MR1_PL (StatSoft) software. One-way or two-way analysis of variance (ANOVA) and then post hoc Duncan multiple range test were carried out to find the significant differences at $p<0.005$ in each experiment. Statistically significant differences were marked as different small letters on graphs and in the table.

Author Contributions: Conceptualization, A.K.; methodology, A.K.; investigation, A.K.; data curation, M.M.P. and A.K.; writing—original draft preparation, A.K.; writing—review and editing, M.M.P. and A.K.; visualization, M.M.P. and A.K.; supervision, M.M.P.; project administration, M.M.P. and A.K. All authors have read and agreed to the published version of the manuscript.

Funding: This research received no external funding.

Institutional Review Board Statement: Not applicable. 
Informed Consent Statement: Not applicable.

Data Availability Statement: Not applicable.

Acknowledgments: We thank Arkadiusz Gajek (Deptment of Medical Biophisicc) for support and help during experimental procedures establishment.

Conflicts of Interest: The authors declare no conflict of interest. The funders had no role in the design of the study; in the collection, analyses, or interpretation of data; in the writing of the manuscript; or in the decision to publish the results.

\section{References}

1. Nicholls, A.M.; Mal, T.K. Effects of lead and copper exposure on growth of an invasive weed, Lythrum salicaria L. (Purple Loosestrife). Ohio J. Sci. 2003, 103, 129-133.

2. Fahr, M.; Laplaze, L.; Bendaou, N.; Hocher, V.; El Mzibri, M.; Bogusz, D.; Smouni, A. Effect of lead on root growth. Front. Plant Sci. 2013, 4, 175. [CrossRef] [PubMed]

3. Kabata-Pendias, A. Trace Elements in Soils and Plants, 4th ed.; CRC press: Boca Raton, FL, USA, 2010; ISBN 9781420093704.

4. Verbruggen, N.; Juraniec, M.; Baliardini, C.; Meyer, C.L. Tolerance to cadmium in plants: The special case of hyperaccumulators. BioMetals 2013, 26, 633-638. [CrossRef]

5. Muszyńska, E.; Hanus-Fajerska, E.; Ciarkowska, K. Studies on lead and cadmium toxicity in Dianthus carthusianorum calamine ecotype cultivated in vitro. Plant Biol. 2018, 20, 474-482. [CrossRef] [PubMed]

6. Wiszniewska, A.; Hanus-Fajerska, E.; Smoleń, S.; Muszyńska, E. In vitro selection for lead tolerance in shoot culture of Daphne species. Acta Sci. Pol. Hortorum Cultus 2015, 14, 129-142.

7. Husejnovic, M.S.; Bergant, M.; Jankovic, S.; Zizek, S.; Smajlovic, A.; Softic, A.; Music, O.; Antonijevic, B. Assessment of Pb, Cd and $\mathrm{Hg}$ soil contamination and its potential to cause cytotoxic and genotoxic effects in human cell lines (CaCo-2 and HaCaT). Environ. Geochem. Health 2018, 40, 1557-1572. [CrossRef] [PubMed]

8. Liu, N.; Lin, Z.; Mo, H. Metal (Pb, Cd, and $\mathrm{Cu}$ )-induced reactive oxygen species accumulations in aerial root cells of the Chinese banyan (Ficus microcarpa). Ecotoxicology 2012, 21, 2004-2011. [CrossRef] [PubMed]

9. Kobylińska, A.; Posmyk, M.M. Melatonin restricts Pb-induced PCD by enhancing BI-1 expression in tobacco suspension cells. BioMetals 2016, 29, 1059-1074. [CrossRef] [PubMed]

10. Kobylińska, A.; Reiter, R.J.; Posmyk, M.M. Melatonin protects cultured tobacco cells against lead-induced cell death via inhibition of cytochrome c translocation. Front. Plant Sci. 2017, 8, 1560. [CrossRef] [PubMed]

11. Coll, N.S.; Epple, P.; Dangl, J.L. Programmed cell death in the plant immune system. Cell Death Differ. 2011, 18, 1247-1256. [CrossRef]

12. Dauphinee, A.N.; Gunawardena, A.N. An overview of programmed cell death research: From canonical to emerging model species. In Plant Programmed Cell Death; Springer: Cham, Switzerland, 2015; ISBN 9783319210339.

13. Dauphinee, A.N.; Fletcher, J.I.; Denbigh, G.L.; Lacroix, C.R.; Gunawardena, A.H.L.A.N. Remodelling of lace plant leaves: Antioxidants and ROS are key regulators of programmed cell death. Planta 2017, 246, 133-147. [CrossRef] [PubMed]

14. Galluzzi, L.; Vitale, I.; Abrams, J.M.; Alnemri, E.S.; Baehrecke, E.H.; Blagosklonny, M.V.; Dawson, T.M.; Dawson, V.L.; El-Deiry, W.S.; Fulda, S.; et al. Molecular definitions of cell death subroutines: Recommendations of the Nomenclature Committee on Cell Death 2012. Cell Death Differ. 2012, 19, 107-120. [CrossRef]

15. Aleksandrushkina, N.I.; Vanyushin, B.F. Endonucleases and their involvement in plant apoptosis. Russ. J. Plant Physiol. 2009, 56, 291-305. [CrossRef]

16. Reape, T.J.; McCabe, P.F. Apoptotic-like regulation of programmed cell death in plants. Apoptosis 2010, 15, 249-256. [CrossRef] [PubMed]

17. Isbat, M.; Zeba, N.; Kim, S.R.; Hong, C.B. A BAX inhibitor-1 gene in Capsicum annuum is induced under various abiotic stresses and endows multi-tolerance in transgenic tobacco. J. Plant Physiol. 2009, 166, 1685-1693. [CrossRef] [PubMed]

18. Martínez-Fábregas, J.; Díaz-Moreno, I.; González-Arzola, K.; Janocha, S.; Navarro, J.A.; Hervás, M.; Bernhardt, R.; VelázquezCampoy, A.; Díaz-Quintana, A.; de la Rosa, M.A. Structural and Functional Analysis of Novel Human Cytochrome c Targets in Apoptosis. Mol. Cell. Proteom. 2014, 13, 1439-1456. [CrossRef]

19. Sun, Y.L.; Zhao, Y.; Hong, X.; Zhai, Z.H. Cytochrome c release and caspase activation during menadione-induced apoptosis in plants. FEBS Lett. 1999, 462, 317-321. [CrossRef]

20. Stein, J.C.; Hansen, G. Mannose induces an endonuclease responsible for DNA laddering in plant cells. Plant Physiol. 1999, 121, 71-80. [CrossRef]

21. Tiwari, B.S.; Belenghi, B.; Levine, A. Oxidative stress increased respiration and generation of reactive oxygen species, resulting in ATP depletion, opening of mitochondrial permeability transition, and programmed cell death. Plant Physiol. 2002, 128, 1271-1281. [CrossRef]

22. Vacca, R.A.; de Pinto, M.C.; Valenti, D.; Passarella, S.; Marra, E.; de Gara, L. Production of reactive oxygen species, alteration of cytosolic ascorbate peroxidase, and impairment of mitochondrial metabolism are early events in heat shock-induced programmed cell death in tobacco bright-yellow 2 cells. Plant Physiol. 2004, 134, 1100-1112. [CrossRef] 
23. Wang, J.; Wang, Y.; Shen, L.; Qian, Y.; Yang, J.; Wang, F. Sulfated lentinan induced mitochondrial dysfunction leads to programmed cell death of tobacco BY-2 cells. Pestic. Biochem. Physiol. 2017, 137, 27-35. [CrossRef] [PubMed]

24. McAinsh, M.R.; Pittman, J.K. Shaping the calcium signature. New Phytol. 2009, 181, 275-294. [CrossRef] [PubMed]

25. Kang, C.H.; Jung, W.Y.; Kang, Y.H.; Kim, J.Y.; Kim, D.G.; Jeong, J.C.; Baek, D.W.; Jin, J.B.; Lee, J.Y.; Kim, M.O.; et al. AtBAG6, a novel calmodulin-binding protein, induces programmed cell death in yeast and plants. Cell Death Differ. 2006, $13,84-95$. [CrossRef] [PubMed]

26. Li, Y.; Li, Q.; Hong, Q.; Lin, Y.; Mao, W.; Zhou, S. Reactive oxygen species triggering systemic programmed cell death process via elevation of nuclear calcium ion level in tomatoes resisting tobacco mosaic virus. Plant Sci. 2018, 270, 166-175. [CrossRef]

27. Choi, H.W.; Lee, D.H.; Hwang, B.K. The Pepper Calmodulin Gene CaCaM1 Is Involved in Reactive Oxygen Species and Nitric Oxide Generation Required for Cell Death and the Defense Response. Mol. Plant-Microbe Interact. 2009, 22, 1389-1400. [CrossRef] [PubMed]

28. Petrosillo, G.; Ruggiero, F.M.; Pistolese, M.; Paradies, G. Reactive oxygen species generated from the mitochondrial electron transport chain induce cytochrome c dissociation from beef-heart submitochondrial particles via cardiolipin peroxidation. Possible role in the apoptosis. FEBS Lett. 2001, 509, 435-438. [CrossRef]

29. Petrosillo, G.; Ruggiero, F.M.; Paradies, G. Role of reactive oxygen species and cardiolipin in the release of cytochrome c from mitochondria. FASEB J. 2003, 17, 2202-2208. [CrossRef]

30. Vacca, R.A.; Valenti, D.; Bobba, A.; Merafina, R.S.; Passarella, S.; Marra, E. Cytochrome c is released in a reactive oxygen speciesdependent manner and is degraded via caspase-like proteases in tobacco bright-yellow 2 cells en route to heat shock-induced cell death. Plant Physiol. 2006, 141, 208-219. [CrossRef] [PubMed]

31. Leborgne-Castel, N.; Jelitto-Van Dooren, E.P.W.M.; Crofts, A.J.; Denecke, J. Overexpression of BiP in tobacco alleviates endoplasmic reticulum stress. Plant Cell 1999, 11, 459-469. [CrossRef]

32. Kołodziejczyk, I.; Posmyk, M.M. Melatonin-a new plant biostimulator? J. Elem. 2016, 21, 1187-1198. [CrossRef]

33. Bałabusta, M.; Szafrańska, K.; Posmyk, M.M. Exogenous melatonin improves antioxidant defense in cucumber seeds (Cucumis sativus L.) germinated under chilling stress. Front. Plant Sci. 2016, 7, 575. [CrossRef]

34. Posmyk, M.M.; Kuran, H.; Marciniak, K.; Janas, K.M. Presowing seed treatment with melatonin protects red cabbage seedlings against toxic copper ion concentrations. J. Pineal Res. 2008, 45, 24-31. [CrossRef] [PubMed]

35. Hasan, M.K.; Ahammed, G.J.; Yin, L.; Shi, K.; Xia, X.; Zhou, Y.; Yu, J.; Zhou, J. Melatonin mitigates cadmium phytotoxicity through modulation of phytochelatins biosynthesis, vacuolar sequestration, and antioxidant potential in Solanum lycopersicum L. Front. Plant Sci. 2015, 6, 601. [CrossRef]

36. Byeon, Y.; Back, K. An increase in melatonin in transgenic rice causes pleiotropic phenotypes, including enhanced seedling growth, delayed flowering, and low grain yield. J. Pineal Res. 2014, 56, 408-414. [CrossRef] [PubMed]

37. Li, C.; Wang, P.; Wei, Z.; Liang, D.; Liu, C.; Yin, L.; Jia, D.; Fu, M.; Ma, F. The mitigation effects of exogenous melatonin on salinity-induced stress in Malus hupehensis. J. Pineal Res. 2012, 53, 298-306. [CrossRef]

38. Zhang, N.; Zhao, B.; Zhang, H.-J.; Weeda, S.; Yang, C.; Yang, Z.-C.; Ren, S.; Guo, Y.-D. Melatonin promotes water-stress tolerance, lateral root formation, and seed germination in cucumber (Cucumis sativus L.). J. Pineal Res. 2013, 54, 15-23. [CrossRef] [PubMed]

39. Wang, P.; Sun, X.; Li, C.; Wei, Z.; Liang, D.; Ma, F. Long-term exogenous application of melatonin delays drought-induced leaf senescence in apple. J. Pineal Res. 2013, 54, 292-302. [CrossRef]

40. Yin, L.; Wang, P.; Li, M.; Ke, X.; Li, C.; Liang, D.; Wu, S.; Ma, X.; Li, C.; Zou, Y.; et al. Exogenous melatonin improves Malus resistance to Marssonina apple blotch. J. Pineal Res. 2013, 54, 426-434. [CrossRef]

41. Kobylińska, A.; Borek, S.; Posmyk, M.M. Melatonin redirects carbohydrates metabolism during sugar starvation in plant cells. J. Pineal Res. 2018, 64, e12466. [CrossRef]

42. Kołodziejczyk, I.; Dzitko, K.; Szewczyk, R.; Posmyk, M.M. Exogenous melatonin expediently modifies proteome of maize (Zea mays L.) embryo during seed germination. Acta Physiol. Plant. 2016, 38, 146. [CrossRef]

43. Bolduc, N.; Brisson, L.F. Antisense down regulation of NtBI-1 in tobacco BY-2 cells induces accelerated cell death upon carbon starvation. FEBS Lett. 2002, 532, 111-114. [CrossRef]

44. Kawai-Yamada, M.; Ohori, Y.; Uchimiya, H. Dissection of Arabidopsis Bax Inhibitor-1 Suppressing Bax-, Hydrogen Peroxide-, and Salicylic Acid-Induced Cell Death. Plant Cell 2004, 16, 21-32. [CrossRef] [PubMed]

45. Vinocur, B.; Altman, A. Recent advances in engineering plant tolerance to abiotic stress: Achievements and limitations. Curr. Opin. Biotechnol. 2005, 16, 123-132. [CrossRef]

46. Mayo, J.C.; Sainz, R.M.; González-Menéndez, P.; Hevia, D.; Cernuda-Cernuda, R. Melatonin transport into mitochondria. Cell. Mol. Life Sci. 2017, 74, 3927-3940. [CrossRef]

47. Reiter, R.J.; Rosales-Corral, S.; Tan, D.X.; Jou, M.J.; Galano, A.; Xu, B. Melatonin as a mitochondria-targeted antioxidant: One of evolution's best ideas. Cell. Mol. Life Sci. 2017, 74, 3863-3881. [CrossRef]

48. Wang, L.; Feng, C.; Zheng, X.; Guo, Y.; Zhou, F.; Shan, D.; Liu, X.; Kong, J. Plant mitochondria synthesize melatonin and enhance the tolerance of plants to drought stress. J. Pineal Res. 2017, 63, e12429. [CrossRef] [PubMed]

49. Chen, H.M.; Zhou, J.; Dai, Y.R. Cleavage of lamin-like proteins in in vivo and in vitro apoptosis of tobacco protoplasts induced by heat shock. FEBS Lett. 2000, 480, 165-168. [CrossRef]

50. Korthout, H.A.A.J.; Berecki, G.; Bruin, W.; van Duijn, B.; Wang, M. The presence and subcellular localization of caspase 3-like proteinases in plant cells. FEBS Lett. 2000, 475, 139-144. [CrossRef] 
51. Zuppini, A.; Baldan, B.; Millioni, R.; Favaron, F.; Navazio, L.; Mariani, P. Chitosan induces Ca 2+-mediated programmed cell death in soybean cells. New Phytol. 2004, 161, 557-568. [CrossRef] [PubMed]

52. Rogers, H.J. Cell Death and Organ Development in Plants. Curr. Top. Dev. Biol. 2005, 71, 225-261. [PubMed]

53. Rogers, H.J. Programmed cell death in floral organs: How and why do flowers die? Ann. Bot. 2006, 97, 309-315. [CrossRef]

54. Lord, C.E.N.; Gunawardena, A.H.L.A.N. Programmed cell death in C. elegans, mammals and plants. Eur. J. Cell Biol. 2012, 91, 603-613. [CrossRef] [PubMed]

55. Panda, S.K.; Yamamoto, Y.; Kondo, H.; Matsumoto, H. Mitochondrial alterations related to programmed cell death in tobacco cells under aluminium stress. C. R. Biol. 2008, 331, 597-610. [CrossRef] [PubMed]

56. Ma, W.; Xu, W.; Xu, H.; Chen, Y.; He, Z.; Ma, M. Nitric oxide modulates cadmium influx during cadmium-induced programmed cell death in tobacco BY-2 cells. Planta 2010, 232, 325-335. [CrossRef] [PubMed]

57. Sainz, R.M.; Mayo, J.C.; Uría, H.; Kotler, M.; Antolfn, I.; Rodriguez, C.; Menendez-Pelaez, A. The pineal neurohormone melatonin prevents in vivo and in vitro apoptosis in thymocytes. J. Pineal Res. 1995, 19, 178-188. [CrossRef] [PubMed]

58. Tian, Y.M.; Li, P.P.; Jiang, X.F.; Zhang, G.Y.; Dai, Y.R. Rejuvenation of degenerative thymus by oral melatonin administration and the antagonistic action of melatonin against hydroxyl radical-induced apoptosis of cultured thymocytes in mice. J. Pineal Res. 2001, 31, 214-221. [CrossRef] [PubMed]

59. Yang, Y.; Jiang, S.; Dong, Y.; Fan, C.; Zhao, L.; Yang, X.; Li, J.; Di, S.; Yue, L.; Liang, G.; et al. Melatonin prevents cell death and mitochondrial dysfunction via a SIRT1-dependent mechanism during ischemic-stroke in mice. J. Pineal Res. 2015, 58, 61-70. [CrossRef] [PubMed]

60. Bouroutzika, E.; Kouretas, D.; Papadopoulos, S.; Veskoukis, A.S.; Theodosiadou, E.; Makri, S.; Paliouras, C.; Michailidis, M.-L.; Caroprese, M.; Valasi, I. Effects of Melatonin Administration to Pregnant Ewes under Heat-Stress Conditions, in Redox Status and Reproductive Outcome. Antioxidants 2020, 9, 266. [CrossRef] [PubMed]

61. Allegra, M.; Reiter, R.J.; Tan, D.X.; Gentile, C.; Tesoriere, L.; Livrea, M.A. The chemistry of melatonin's interaction with reactive species. J. Pineal Res. 2003, 34, 1-10. [CrossRef]

62. Fischer, T.W.; Kleszczyński, K.; Hardkop, L.H.; Kruse, N.; Zillikens, D. Melatonin enhances antioxidative enzyme gene expression (CAT, GPx, SOD), prevents their UVR-induced depletion, and protects against the formation of DNA damage (8-hydroxy-2'deoxyguanosine) in ex vivo human skin. J. Pineal Res. 2013, 54, 303-312. [CrossRef]

63. Gitto, E.; Tan, D.-X.; Reiter, R.J.; Karbownik, M.; Manchester, L.C.; Cuzzocrea, S.; Fulia, F.; Barberi, I. Individual and synergistic antioxidative actions of melatonin: Studies with vitamin E, vitamin C, glutathione and desferrrioxamine (desferoxamine) in rat liver homogenates. J. Pharm. Pharmacol. 2001, 53, 1393-1401. [CrossRef] [PubMed]

64. Lei, X.Y.; Zhu, R.Y.; Zhang, G.Y.; Dai, Y.R. Attenuation of cold-induced apoptosis by exogenous melatonin in carrot suspension cells: The possible involvement of polyamines. J. Pineal Res. 2004, 36, 126-131. [CrossRef] [PubMed]

65. Matsumura, H.; Nirasawa, S.; Kiba, A.; Urasaki, N.; Saitoh, H.; Ito, M.; Kawai-Yamada, M.; Uchimiya, H.; Terauchi, R. Overexpression of Bax inhibitor suppresses the fungal elicitor-induced cell death in rice (Oryza sativa L.) cells. Plant J. 2003, 33, 425-434. [CrossRef]

66. Wang, X.; Tang, C.; Huang, X.; Li, F.; Chen, X.; Zhang, G.; Sun, Y.; Han, D.; Kang, Z. Wheat BAX inhibitor-1 contributes to wheat resistance to Puccinia striiformis. J. Exp. Bot. 2012, 63, 4571-4584. [CrossRef] [PubMed]

67. Giorgi, C.; Baldassari, F.; Bononi, A.; Bonora, M.; de Marchi, E.; Marchi, S.; Missiroli, S.; Patergnani, S.; Rimessi, A.; Suski, J.M.; et al. Mitochondrial Ca2+ and apoptosis. Cell Calcium 2012, 52, 36-43. [CrossRef] [PubMed]

68. Ma, Y.; Walker, R.K.; Zhao, Y.; Berkowitz, G.A. Linking ligand perception by PEPR pattern recognition receptors to cytosolic Ca2+ elevation and downstream immune signaling in plants. Proc. Natl. Acad. Sci. USA 2012, 109, 19852-19857. [CrossRef] [PubMed]

69. Kacprzyk, J.; Brogan, N.P.; Daly, C.T.; Doyle, S.M.; Diamond, M.; Molony, E.M.; McCabe, P.F. The retraction of the protoplast during PCD is an active, and interruptible, calcium-flux driven process. Plant Sci. 2017, 260, 50-59. [CrossRef]

70. Collazo, C.; Chacón, O.; Borrás, O. Programmed cell death in plants resembles apoptosis of animals. Biotecnol. Apl. 2006, 23, 1-10.

71. Krishnamurthy, K.V.; Krishnaraj, R.; Chozhavendan, R.; Christopher, F.S. The program of cell death in plants and animals: A comparison. Curr. Sci. 2000, 79, 1169-1181.

72. Suofu, Y.; Li, W.; Jean-Alphonse, F.G.; Jia, J.; Khattar, N.K.; Li, J.; Baranov, S.V.; Leronni, D.; Mihalik, A.C.; He, Y.; et al. Dual role of mitochondria in producing melatonin and driving GPCR signaling to block cytochrome c release. Proc. Natl. Acad. Sci. USA 2017, 114, E7997-E8006. [CrossRef] [PubMed]

73. Coll, N.S.; Vercammen, D.; Smidler, A.; Clover, C.; Van Breusegem, F.; Dangl, J.L.; Epple, P. Arabidopsis type I metacaspases control cell death. Science 2010, 330, 1393-1397. [CrossRef] [PubMed]

74. Tran, V.; Weier, D.; Radchuk, R.; Thiel, J.; Radchuk, V. Caspase-Like Activities Accompany Programmed Cell Death Events in Developing Barley Grains. PLoS ONE 2014, 9, e109426. [CrossRef] [PubMed]

75. Sueldo, D.J.; van der Hoorn, R.A.L. Plant life needs cell death, but does plant cell death need Cys proteases? FEBS J. 2017, 284, 1577-1585. [CrossRef]

76. Hara-Nishimura, I.; Hatsugai, N. The role of vacuole in plant cell death. Cell Death Differ. 2011, 18, 1298-1304. [CrossRef]

77. Hatsugai, N.; Iwasaki, S.; Tamura, K.; Kondo, M.; Fuji, K.; Ogasawara, K.; Nishimura, M.; Hara-Nishimura, I. A novel membrane fusion-mediated plant immunity against bacterial pathogens. Genes Dev. 2009, 23, 2496-2506. [CrossRef]

78. Szafrańska, K.; Reiter, R.J.; Posmyk, M.M. Melatonin Improves the Photosynthetic Apparatus in Pea Leaves Stressed by Paraquat via Chlorophyll Breakdown Regulation and Its Accelerated de novo Synthesis. Front. Plant Sci. 2017, 8, 878. [CrossRef] [PubMed] 
79. Hevia, D.; González-Menéndez, P.; Quiros-González, I.; Miar, A.; Rodríguez-García, A.; Tan, D.-X.; Reiter, R.J.; Mayo, J.C.; Sainz, R.M. Melatonin uptake through glucose transporters: A new target for melatonin inhibition of cancer. J. Pineal Res. 2015, 58, 234-250. [CrossRef]

80. Huo, X.; Wang, C.; Yu, Z.; Peng, Y.; Wang, S.; Feng, S.; Zhang, S.; Tian, X.; Sun, C.; Liu, K.; et al. Human transporters, PEPT1/2, facilitate melatonin transportation into mitochondria of cancer cells: An implication of the therapeutic potential. J. Pineal Res. 2017, 62, e12390. [CrossRef] [PubMed]

81. Kołodziejczyk, I.; Bałabusta, M.; Szewczyk, R.; Posmyk, M.M. The levels of melatonin and its metabolites in conditioned corn (Zea mays L.) and cucumber (Cucumis sativus L.) seeds during storage. Acta Physiol. Plant. 2015, 37, 105. [CrossRef]

82. Nuydens, R.; Novalbos, J.; Dispersyn, G.; Weber, C.; Borgers, M.; Geerts, H. A rapid method for the evaluation of compounds with mitochondria- protective properties. J. Neurosci. Methods 1999, 92, 153-159. [CrossRef]

83. Ganju, N.; Eastman, A. Zinc inhibits Bax and Bac activation and cytochrome c release induced by chemical inducers of apoptosis but not by death-receptor-intiated pathways. Cell Death Differ. 2003, 10, 652-661. [CrossRef] [PubMed]

84. Kobylinska, A.; Bednarek, J.; Blonski, J.Z.; Hanausek, M.; Walaszek, Z.; Robak, T.; Kilianska, Z.M. In vitro sensitivity of B-cell chronic lymphocytic leukemia to cladribine and its combinations with mafosfamide and/or mitoxantrone. Oncol. Rep. 2006, 16, 1389-1395. [CrossRef]

85. Laemmli, U.K. Cleavage of structural proteins during the assembly of the head of bacteriophage T4. Nature 1970, 227, 680-685. [CrossRef] [PubMed]

86. Towbin, H.; Staehelin, T.; Gordon, J. Electrophoretic transfer of proteins from polyacrylamide gels to nitrocellulose sheets: Procedure and some applications. Proc. Natl. Acad. Sci. USA 1979, 76, 4350-4354. [CrossRef]

87. Leary, J.J.; Brigati, D.J.; Ward, D.C. Rapid and sensitive colorimetric method for visualizing biotin-labeled DNA probes hybridized to DNA or RNA immobilized on nitrocellulose: Bio-blots. Proc. Natl. Acad. Sci. USA 1983, 80, 4045-4049. [CrossRef] [PubMed]

88. Guerrero, J.R.; García-Ruíz, P.; Sánchez-Bravo, J.; Acosta, M.; Arnao, M.B. Quantitation of indole-3-acetic acid by LC with electrochemical detection in etiolated hypocotyls of Lupinus albus. J. Liq. Chromatogr. Relat. Technol. 2001, 24, 3095-3104. [CrossRef]

89. Hernández-Ruiz, J.; Cano, A.; Arnao, M.B. Melatonin: A growth-stimulating compound present in lupin tissues. Planta 2004, 220, 140-144. [CrossRef] [PubMed] 